Article

\title{
Financial Literacy in Japan: New Evidence Using Financial Knowledge, Behavior, and Attitude
}

\author{
Yoshihiko Kadoya ${ }^{(1)}$ and Mostafa Saidur Rahim Khan *(1) \\ Department of Economics, Hiroshima University, 1-2-1 Kagamiyama, Higashi Hiroshima, Hiroshima 739-8525, \\ Japan; ykadoya@hiroshima-u.ac.jp \\ * Correspondence: khan@hiroshima-u.ac.jp
}

Received: 17 March 2020; Accepted: 1 May 2020; Published: 2 May 2020

check for updates

\begin{abstract}
Success in the current complex and sophisticated financial marketplaces depends on the ability of people to make sustainable financial decisions to improve their future well-being, for which financial literacy is a pathway. This study examines the relationship between the demographic and socio-economic factors and financial literacy in Japan by segregating financial literacy into financial knowledge, attitude, and behavior, and providing a deeper understanding of the relationships. The methodology included using data from the Financial Literacy Survey 2016 by the Central Council for Financial Services Information of Japan. We used a linear regression model to explain how demographic and socio-economic factors relate to financial knowledge, attitude, and behavior. Results show that education, the balance of financial assets, and the use of financial information are positively related, while the experience of financial trouble is negatively related to financial knowledge, attitude, and behavior. We show that males are more financially knowledgeable than females, but females are more positive than males with regard to financial behavior and financial attitude. Age is positively related to financial knowledge but negatively related to financial attitude, thus suggesting that middle-aged people in Japan are more financially knowledgeable, but younger and older people are more positive with regard to financial behavior and attitude. The findings have implications for policymakers.
\end{abstract}

Keywords: financial literacy; financial knowledge; financial behavior; financial attitude; demographic and socio-economic characteristics

JEL Classification: D14; D19; D10

\section{Introduction}

Financial literacy has gained much interest from academia and policymakers in the last few decades because of its relevance to people's sustainable economic and financial decisions to improve their future well-being. The growing complexity of financial and commodity markets could lead unaware consumers to make poor choices. The necessity of financial literacy is conceived because of consumers' lack of knowledge and susceptibility to making wrong decisions [1-3]. In a modern society, people often struggle with financial problems and face various crises of their own. The extent of government regulations in an open market economy can only give some protection, but never guarantee success in financial and economic transactions. Hence, the government's initiative to spread financial literacy among people is highly desirable. A concerted effort from the government and other competent authorities would facilitate financial literacy among the masses. Financial literacy enables people to understand the nature and behavior of financial and economic issues. Previous studies found a relationship between financial literacy and retirement savings plans, insurance policies, wealth accumulation, consumption decisions, and stock market investments [4-8]. Financial literacy at the firm 
level was found to be helpful for its sustainable development [9]. There is a dire need for formal and informal financial education in the countries to improve financial literacy conditions. Shim et al. [10] argued that financial education at home and schools helps to acquire financial knowledge, which also shapes people's attitude and financial behavioral intentions. Emphasizing the importance of financial literacy, the US government created the Financial Literacy and Education Commission after enacting the Financial Literacy and Education Act in 2003. A non-profit organization called the Jump\$tart Coalition for Personal Financial Literacy (based in Washington, D.C.) was created in 1995 to encourage financial literacy among young people. A declaration by the G20 leaders in 2012 prioritized the development of national strategies for financial education. The "Agenda for Finance and Economics Education in 2005" and "Financial Education program in 2007" show the Japanese government's initiative to propagate financial literacy among its citizens [11]. The program designed financial education for Japanese students depending on age. In response to the G20 declaration, the Financial Services Agency of Japan (FSA) organized a study group in 2012, which set minimum requirements for financial literacy education in Japan. In addition, the Central Council for Financial Services Information (CCFSI) formed a committee in 2013 to promote financial education [11]. These initiatives demonstrate how governments prioritize financial literacy in national strategies. Despite all of these efforts, financial education at the school level is inadequate to foster proper financial knowledge among students. The financial education curriculum is not well organized. Moreover, there are inadequate qualified teachers to disseminate financial education at the school level [12]. The informal financial education is barely present in the country. Experts have put in some effort to conduct television programs and training arrangements for professionals. There should be a concerted effort from the government, different committees, and research groups to implement the suggested programs in the country. Since the ministry of education is responsible for formulating the national education program, they must coordinate the whole effort to expand financial education throughout the country.

Financial literacy, as used in the academic literature, is predominantly based on financial knowledge as the basis for its measurement. Despite consensus on the importance of financial literacy, its definition and measurement differ greatly across agencies and research studies. Marcolin and Abraham [13] emphasized the need to find a standard measure of financial literacy. Moreover, Schmeiser and Seligman [14] found problems measuring financial literacy because respondents do not answer financial literacy questions consistently. Thus, researchers need an appropriate definition and measurement of financial literacy to understand its outcomes. Huston [15] founds several important facts regarding existing definitions and measurement techniques for financial literacy in a review of seventy studies. First, most studies did not include a definition and used financial literacy and financial knowledge interchangeably. Second, most studies with definitions relied on either ability or knowledge, but the US Financial Literacy and Education Commission and Jump\$tart Coalition for Personal Financial Literacy used both financial knowledge and ability in their definition. The Financial Literacy and Education Commission [16] defines financial literacy as "the ability and awareness to use knowledge and skills to manage financial resources to achieve maximum financial well-being," while Jump\$tart Coalition for Personal Financial Literacy [17] defines it as "the ability to use knowledge and skills to manage one's financial resources effectively for lifetime financial security." It is evident that all of these institutions define financial literacy from the viewpoint of financial knowledge and the ability to understand financial issues. People's ability to convert financial knowledge into practice was largely ignored until the Organization for Economic Co-operation and Development (OECD) incorporated it into their definition of financial literacy. The OECD defines financial literacy as "the knowledge and understanding of financial concepts and risks, and the skills, motivation, and confidence to apply this knowledge and understanding to make effective decisions across a range of financial contexts, to improve the financial well-being of individuals and society, and to enable participation in economic life" $[18,19]$.

Several studies worldwide utilized demographic and socio-economic determinants of financial literacy using conventional definitions of it that measure people's understanding of financial concepts. 
Van Rooij, Lusardi, and Alessie [5]; Alessie et al. [20]; Brown and Graf [21]; Hung, Yoong, and Brown [22]; Lusardi and Mitchell [23]; Atkinson and Messy [19]; Kadoya et al. [24]; Kadoya and Khan [25,26]; Kadoya et al. [27]; Watanapongvanich et al. [28]; and Sekita [29] provide evidence that men are more financially literate than women. Others report a significant non-linear age effect on financial literacy. Middle-aged people are more financially literate than younger and older people $[7,30,31]$. Agarwal et al. [32] argued that people become more financially literate through experience but begin to lose financial literacy in old age due to decreases in cognitive ability. Researchers argue that education enhances cognitive ability, which in turn increases financial literacy [33]. Lusardi and Mitchell [7,31]; Lusardi, Mitchell, and Curto [30]; and Danes and Haberman [34] provide empirical evidence of the positive relationship between education and financial literacy. Urban et al. [35] argued that financial education requirements at the school level were associated with better credit outcomes. Lusardi and Mitchell [23] found that employed people tend to be more financially literate than their unemployed counterparts are due to the experience they gather from the workplace. Earning capacity and asset balance could be important contributors to financial literacy as well. Atkinson and Messy [19], Monticone [36], Lusardi and Tufano [37], and Guiso and Jappelli [38] showed that household income and assets contribute positively to financial literacy. However, findings of previous studies are based on financial knowledge as the basis for measuring financial literacy. Financial behavior or the financial attitude of people has rarely been studied as a component of financial literacy, although positive outcomes of financial literacy largely depend on people's financial behavior [19].

The objective of this study is to examine the relationship between demographic and socio-economic factors and financial literacy from a broader perspective by dividing financial literacy into financial knowledge, attitude, and behavior. Our measure of financial knowledge, behavior, and attitude generally follows the definition of financial literacy provided by the OECD [18,19], which focuses on operationalizing financial knowledge in addition to understanding financial concepts. Given the lack of study on the role of financial behavior and attitude in understanding financial literacy, we use a new and large-scale survey conducted by the Central Council for Financial Services Information of Japan to provide evidence on financial literacy from the viewpoint of financial knowledge, behavior, and attitude. Our study contributes to the existing literature in at least three ways. First, to the best of our knowledge, this is the first study in Japan that examines the factors affecting financial literacy in terms of financial knowledge, financial attitudes, and financial behavior. Previous studies mostly followed Lusardi and Mitchell's [39,40] methodology, which uses questions to measure financial knowledge $[8,26,27,29]$. Second, this study provides evidence on the interrelationships among financial knowledge, behavior, and attitude. Finally, this study examines how demographic and socio-economic factors are associated with financial knowledge, behavior, and attitude.

The rest of the paper proceeds as follows. Section 2 describes the data and the methodology, Section 3 discusses the empirical findings, Section 4 discusses the empirical findings, and Section 5 concludes.

\section{Data and Methodology}

\subsection{Study Data}

This study uses data from a large-scale questionnaire survey called the Financial Literacy Survey 2016 by the Central Council for Financial Services Information of Japan that collected information on the financial knowledge and financial decision-making skills of individuals over 18 years of age. The online survey was conducted throughout Japan between February 2016 and March 2016. The full sample consists of 25,000 individuals between 18 and 79 years old and covers all prefectures and major cities, chosen based on the proportion of Japan's demographic features. Samples were selected randomly to satisfy the sample composition ratio. Participants registered with the survey company were sent an e-mail requesting participation in the survey. Respondents accessed the designated URL containing the survey questions and answered them on the website. The questions were a combination 
of true or false, qualitative statements, and multiple-choice questions and were designed in accordance with the National Financial Capability Study of the US Financial Industry Regulatory Authority [41] and the OECD. Our study uses a sample of 16,345 respondents who responded to all the questions.

\subsection{Variables and Measurement Issues}

\subsubsection{Dependent Variable}

In this study, we measured financial knowledge, financial behavior, and financial attitude to understand various aspects of financial literacy. These three components of financial literacy are the dependent variables in this study. Given the challenges of using traditional questions about financial knowledge to measure financial literacy accurately [14], we adopted the methodology of the OECD $[18,19]$ in measuring financial literacy from a broader perspective. We argue that this provides a more accurate measure of financial literacy, because high scores on financial knowledge, attitude, and behavior reflect that respondents are not only knowledgeable but can also translate this knowledge into financial decision-making.

Financial knowledge: Financial knowledge measures the ability to understand financial calculations, specifically the implications of interest rates, inflation, and the risk and return on financial securities. Financial knowledge develops into the skills necessary to moderate people's financial behavior and attitude. We used the questions below to measure financial knowledge. We assigned 1 for each correct answer and 0 for each wrong answer. The financial knowledge score is obtained by averaging the total score obtained from answering the questions correctly. Thus, it ranges between 0 and 1.

Suppose you put 1 million yen into a savings account with a guaranteed interest rate of $2 \%$ per year.

- If no further deposits or withdrawals are made, how much would be in the account after one year, once the interest payment is made?

- Then, how much would be in the account after five years?

- Does high inflation mean that the cost of living is increasing rapidly?

- Is an investment with a high return likely to be high-risk?

- Does buying a single company's stock usually provide a safer return than a stock mutual fund?

Financial Behavior: Financial behavior is an important element of financial literacy, which measures how people act in financial transactions. In other words, it measures whether they skillfully utilize financial knowledge to make better financial decisions. Generally, positive outcomes of financial knowledge depend on how positively people behave financially. We used the following qualitative statements to measure financial behavior. The statements were measured on a five-point Likert scale, where $1=$ strongly agree and $5=$ strongly disagree. We assigned 1 point for respondents who put themselves at 1 or 2 on the scale and assigned 0 otherwise. The financial behavior score is obtained by averaging the total score. Thus, it ranges between 0 and 1 . We considered higher scores as a reflection of positive behavior.

- Before I buy something, I carefully consider whether I can afford it.

- I pay my bills on time.

- I set long-term financial goals and strive to achieve them.

- I keep a close personal watch on my financial affairs.

Financial attitude: Financial attitude, which measures people's outlook toward financial issues, is also an important element of financial literacy. The yardstick to measure financial attitude is whether people place enough emphasis on their financial issues to secure future benefits. If people have a negative attitude towards financial issues regarding future security (e.g., future savings), they will 
be less likely to secure their future. Similarly, if people place higher importance on short-term wants over long-term security, they are less likely to save for the future and make long term financial plans. Financial attitude does not consider the capacity of people to save more for the future. Rather, it focuses on whether people place enough importance on future financial security. It is related to the present bias avoidance, which indicates people's positive financial attitude desire to secure their future. A positive financial attitude is, thus, related to a sustainable financial decision. Both the questions that have been used to measure financial attitude in this study are related to people's present bias; that is, whether people place higher importance on the present or on the future. People are assumed to have a positive financial attitude if they avoid present bias in favor of the future. Thus, placing higher importance on future savings rather than current consumption is a sign of a positive financial attitude. Xiao and Porto [42] provided evidence that present-biased consumers are more likely to spend in the present and less likely to save for the future. The main difference between financial behavior and financial attitude is that financial behavior refers to actual financial transactions or efforts made by people, while financial attitude refers to people's outlook. For example, having a long-term financial goal is related to financial attitude while investing in pension schemes, saving for a rainy day, or investing in profitable ventures are related to financial behavior. Although financially knowledgeable and skillful people are more likely to have a positive attitude towards financial transactions, it is not always true [43]. Sometimes, people may fail to translate their knowledge and skills into attitude. We used the following statements to measure financial attitude:

- I find it more satisfying to spend money than to save it for the long term.

- I tend to live for today and let tomorrow take care of itself.

Both statements were measured on a 5-point Likert scale, where $1=$ strongly agree and $5=$ strongly disagree. We assigned 1 point for respondents who put themselves at 1 or 2 on the scale and assigned 0 otherwise. The financial attitude score is obtained by averaging the total score. Thus, it ranges between 0 and 1 . We considered higher scores as a reflection of a positive attitude.

We also constructed a full measure of financial literacy, which includes all three components. The overall financial literacy is measured by averaging the values of financial knowledge, behavior, and attitude. In addition to the three components, the overall measure of financial literacy is also used as a dependent variable of this study.

Table 1 reports the interrelationships among financial knowledge, attitude, and behavior of the survey respondents. The results show a significantly positive relationship among financial knowledge, behavior, and attitude. The results support the implications of the conceptual model developed by Shim et al. [10], where they showed that financial knowledge, behavior, and attitude are interlinked through financial socialization agents, demographics, and personal values. Their results suggest that self-actualizing personal values and financial education at home and school help to acquire financial knowledge, which also shapes their attitude and financial behavioral intentions.

Table 1. Relationship among financial knowledge, behavior, and attitude.

\begin{tabular}{cccc}
\hline & Financial Knowledge & Financial Behavior & Financial Attitude \\
\hline Financial knowledge & 1 & & \\
Financial behavior & 0.2272 & 1 & \\
& $(0.00)$ & 0.3979 & 1 \\
Financial attitude & 0.2151 & $(0.00)$ & 1 \\
\hline
\end{tabular}

Note: $p$ values within parentheses.

\subsubsection{Independent Variables}

To explain financial knowledge, behavior, and attitude in Japan, we include several variables related to respondents' demographic and socio-economic characteristics. We include gender because 
it appears to be an important feature related to financial literacy. Gender is a well-studied issue in the literature of financial literacy. Previous studies found that males are more financially literate than females [5,19,20,22,40]. Kadoya and Khan [26] and Sekita [8,29] found similar evidence for Japan. In this study, we have used gender as a categorical variable, where 0 indicates females and 1 indicates males. We also include age because previous studies found a non-linear relationship with financial literacy, in which financial literacy is higher for middle-aged respondents as compared to younger and older respondents $[7,29,30]$. Given the probable non-linear relationship, we included an "age squared" variable in the model as well. In this study, age indicates the actual age of respondents and has been used as a continuous variable. We include respondents' education because education enhances money management capacity and cognitive ability, which contribute to attaining financial literacy $[29,30,33]$. We coded respondents' education as the actual years of education received by the respondents, which they reported as 9 years (middle school graduate), 12 years (high school graduate), 14 years (specialized training college or junior college/ college of technology graduate), 16 years (university graduate), 18 years (postgraduate; master's), and 21 years (postgraduate; Ph.D.). Respondents' employment status is also an important predictor of financial literacy. Lusardi and Mitchell [23] found that employed respondents were more literate than their unemployed counterparts are. We used respondents' employment status as a categorical variable where 1 indicates that respondents are company employees, government employees, self-employed, and part-time employed and 0 indicates that respondents are not conventionally employed in any formal institution but rather are full-time homemakers, students, unemployed, retired, or engaged in unspecified sectors. Thus, the employment status variable does not merely indicate whether respondents are employed or not but rather indicates the condition of their employment. Financial conditions, as reflected by household income and balance of assets, can also explain financial literacy. There is sufficient evidence from empirical studies that household income and assets are positively linked to financial literacy [26,37,38]. We used both the income and financial assets variables as continuous variables.

In addition to these traditional demographic and socio-economic variables, we included two new variables that prior studies did not use to examine their relationship with financial literacy: respondents' experience with financial trouble, assuming that such experiences in the recent past are negatively related to financial literacy; and willingness to acquire financial knowledge from newspapers, magazines, television, and the internet as a predictor of financial literacy, since people who acquire financial information are more likely to be financially literate. Both variables have been used as categorical variables.

Table 2 provides the summary statistics of the variables used in this study. Respondents' average financial knowledge, behavior, and attitude scores are 0.63 (standard deviation $(\mathrm{SD})=0.32$ ), 0.67 $(\mathrm{SD}=0.31)$, and $0.46(\mathrm{SD}=0.41)$, respectively. The demographic and socio-economic background of the respondents indicates that more than half are male $(53 \%)$, are 48.69 years old on average (SD $=16.49)$, earn an average yearly income of 5.15 million yen ( $\mathrm{SD}=3.19$ million yen), have a 7.31 million yen balance of financial assets (SD $=7.19$ million yen), $58.67 \%$ are either fully employed or have some part-time jobs, have more than a college level education (mean $=14.26$ years and SD $=2.06$ years), only $6.64 \%$ faced financial trouble, and $58.12 \%$ often acquire financial and economic information.

Table 2. Descriptive statistics.

\begin{tabular}{cccccc}
\hline Variable & Observations & Mean & SD & Min & Max \\
\hline Financial knowledge & 16,345 & 0.6300 & 0.3239 & 0 & 1 \\
Financial behavior & 16,345 & 0.6655 & 0.3105 & 0 & 1 \\
Financial attitude & 16,345 & 0.4624 & 0.4140 & 0 & 1 \\
Male & 16,345 & 0.5325 & 0.4990 & 0 & 1 \\
Age & 16,345 & 48.6849 & 16.4930 & 18 & 79 \\
\hline
\end{tabular}


Table 2. Cont.

\begin{tabular}{cccccc}
\hline Variable & Observations & Mean & SD & Min & Max \\
\hline Employed & 16,345 & 0.5867 & 0.4924 & 0 & 1 \\
Education & 16,345 & 14.2572 & 2.0589 & 9 & 18 \\
Financial trouble & 16,345 & 0.0664 & 0.2490 & 0 & 1 \\
Financial information & 16,345 & 0.5812 & 0.4934 & 0 & 1 \\
Income (million yen) & 16,345 & 5.1515 & 3.1850 & 0 & 15 \\
Financial assets (million yen) & 16,345 & 7.3100 & 7.1879 & 0 & 20 \\
\hline
\end{tabular}

Note: SD stands for standard deviation.

Table 3 shows the distribution of financial knowledge, financial behavior, and financial attitude based on demographic features such as age, gender, and education. The results show a positive trend of age with financial knowledge, behavior, and attitude. We divided respondents into three age groups: younger than 40 years, between 40 and 64 years, and older than 64 years. In all components of financial literacy, older respondents scored higher than middle-aged and younger respondents. We have interesting results when dividing the components of financial literacy based on gender. Males scored higher on financial knowledge than females. However, females scored higher on financial behavior and financial attitude than males. We divided respondents into three education groups: less than 12 years (below college level), between 12 and 14 years (college level), and more than 16 years (postgraduate level). The distribution of financial literacy components across education groups also shows a positive trend. In all components of financial literacy, highly educated respondents performed better than their less-educated counterparts.

Table 3. Distribution of financial literacy by age, gender, and education.

\begin{tabular}{ccccc}
\hline \multirow{2}{*}{ Variables } & $\begin{array}{c}\text { Financial } \\
\text { Knowledge }\end{array}$ & $\begin{array}{c}\text { Financial } \\
\text { Behavior }\end{array}$ & $\begin{array}{c}\text { Financial } \\
\text { Attitude }\end{array}$ \\
\hline \multirow{3}{*}{ Age } & $<40$ years & 0.5342 & 0.6224 & 0.4044 \\
& $40-64$ years & 0.6573 & 0.6617 & 0.4730 \\
Gender & $>64$ years & 0.7227 & 0.7069 & 0.5295 \\
& Male & 0.6903 & 0.6558 & 0.4389 \\
\multirow{2}{*}{ Education } & Female & 0.5613 & 0.6765 & 0.4891 \\
& Below college level & 0.4164 & 0.5710 & 0.3697 \\
& College level & 0.5663 & 0.6548 & 0.4637 \\
& Postgraduate level & 0.7068 & 0.6876 & 0.4773 \\
\hline
\end{tabular}

\subsection{Methodology}

We used an ordinary least squares (OLS) regression model to explain how demographic and socio-economic factors relate to financial knowledge, attitude, behavior, and the overall measure of financial literacy. We used four models for the three components and a full measure of financial literacy, which includes all three components. Models 1,2,3, and 4 use financial knowledge, financial behavior, financial attitude, and financial literacy, respectively, as dependent variables. All models include the independent variables of gender, age, education, employment status, income, financial assets, financial trouble, and financial information. The linear regression model is:

Financial knowledge or financial behavior or financial attitude or financial literacy

$$
\begin{aligned}
& =\alpha+\beta_{1} \text { male }+\beta_{2} \text { age }+\beta_{3} \text { age }_{\text {sq }}+\beta_{4} \text { education }+\beta_{5} \text { income } \\
& +\beta_{6} \text { financial assets }+\beta_{7} \text { employed }+\beta_{8} \text { financial trouble } \\
& +\beta_{9} \text { financial information }+\varepsilon_{i}
\end{aligned}
$$

As a measure to check the robustness of results, we also used a generalized structural equation model in logit (GSEM in logit), where a score of more than 0.5 indicates higher financial knowledge, 
behavior, attitude, and overall financial literacy, and a lower score indicates otherwise. The dependent variable of the logit model takes the value 1 for more financially literate respondents (respondents with more financial knowledge, positive behavior, and attitude) and 0 for less financially literate respondents. The independent variables remained the same as in the linear regression model. Previous studies argued that endogeneity is an important issue in the study of financial literacy, which could produce biased results [23]. The GSEM in the logit model controlled the possible endogeneity bias in the coefficients by including common, unobserved components in the equations for many variables. Like the linear regression model, we used four GSEM in logit models to explain financial knowledge, behavior, attitude, and overall financial literacy. The GSEM in logit model is:

Financial knowledge or financial behavior or financial attitude or financial literacy (1

$=$ financially more literate and $0=$ financially less literate)

$=\alpha+\beta_{1}$ male $+\beta_{2}$ age $+\beta_{3}$ age $_{\text {sq }}+\beta_{4}$ education $+\beta_{5}$ income

$+\beta_{6}$ financialassets $+\beta_{7}$ employment status $+\beta_{8}$ financial trouble

$+\beta_{9}$ financial information $+\varepsilon_{i}$

\section{Results}

Table 4 reports the OLS regression coefficients for the demographic and socio-economic factors explaining financial knowledge, behavior, attitude, and overall financial literacy. Models 1, 2, 3, and 4 show the regression coefficients for financial knowledge, financial behavior, financial attitude, and overall financial literacy, respectively. The coefficients for model 1 show a positive relationship between financial knowledge and male gender, age, education, income, the balance of financial assets, and use of financial information, and a negative relationship between financial knowledge and both age squared and experience of financial trouble. The significantly positive coefficient of age and negative coefficient of age squared indicate a non-linear positive relationship between financial knowledge and age. We found no relationship between respondents' condition of being employed and financial knowledge. While the relationship of most of the variables is similar for all three components of financial literacy, interestingly, we found a different relationship between some demographic variables and both financial behavior and financial attitude. The coefficients for model 2 show that education, the balance of financial assets, and the use of financial information are positively associated with financial behavior. However, unlike financial knowledge, males are negatively associated with financial behavior. Other variables, such as being employed and the experience of financial trouble, are negatively related to financial literacy. We found no relationship of respondents' income and age with financial behavior. The coefficients for model 3 show that education, the balance of financial assets, and the use of financial information are positively associated with financial attitude. Unlike financial knowledge, but similar to financial behavior, we found a negative relationship between males and financial attitude. Unlike financial knowledge, financial attitude is negatively related to age. Experiencing financial troubles and the condition of being employed are negatively related to age, but we found no relationship of respondents' income to financial attitude. The coefficients for model 4 show a positive relationship of the overall financial literacy with males, age, education, income, the balance of financial assets, and use of financial information; they show a negative relationship of the overall financial literacy with the condition of being employed and experience of financial trouble. Results show that the relationship of most of the variables with the overall measure of financial literacy is very similar to all three components of financial literacy but differ with financial behavior and financial attitude with regards to male gender and age. Male gender and age are positively associated with financial knowledge and the overall measure of financial literacy but are negatively associated with financial behavior and financial attitude. 
Table 4. Ordinary least squares (OLS) regression coefficients.

\begin{tabular}{ccccc}
\hline & $\begin{array}{c}\text { Model 1 (Financial } \\
\text { Knowledge) }\end{array}$ & $\begin{array}{c}\text { Model 2 (Financial } \\
\text { Behavior) }\end{array}$ & $\begin{array}{c}\text { Model 3 (Financial } \\
\text { Attitude) }\end{array}$ & $\begin{array}{c}\text { Model 4 (Financial } \\
\text { Literacy) }\end{array}$ \\
\hline Male & $0.0873(18.17)^{* * *}$ & $-0.0370(-7.33)^{* * *}$ & $-0.0583(-8.62)^{* * *}$ & $0.0156(4.28)^{* * *}$ \\
Age & $0.0050(5.02)^{* * *}$ & $-0.0015(-1.36)$ & $-0.0040(-2.89)^{* * *}$ & $0.0025(3.30)^{* * *}$ \\
Age_sq & $-0.0000(-1.74)^{*}$ & $0.0000(1.17)$ & $-0.0000(-2.16)^{* *}$ & $-0.0000(-1.18)$ \\
Education & $0.0238(20.49)^{* * *}$ & $0.0066(5.38)^{* * *}$ & $0.0063(3.86)^{* * *}$ & $0.0143(16.28)^{* * *}$ \\
Income & $0.0049(5.84)^{* * *}$ & $-0.0002(-0.24)$ & $-0.0013(-1.11)$ & $0.0019(3.00)^{* * *}$ \\
Financial assets & $0.0070(18.16)^{* * *}$ & $0.0073(18.01)^{* * *}$ & $0.0103(19.08)^{* * *}$ & $0.0077(26.38)^{* * *}$ \\
Employed & $-0.0051(-0.91)$ & $-0.0159(-2.72)^{* * *}$ & $-0.0252(-3.22)^{* * *}$ & $-0.0127(-3.00)^{* * *}$ \\
Financial trouble & $-0.0198(-2.20)^{* *}$ & $-0.0655(-6.93)^{* * *}$ & $-0.0826(-6.52)^{* * *}$ & $-0.0478(-7.01)^{* * *}$ \\
Financial & $0.1370(28.65)^{* * *}$ & $0.0949(18.87)^{* * *}$ & $0.0652(9.68)^{* * *}$ & $0.1086(29.93)^{* * *}$ \\
information & $-0.1013(-3.87)^{* * *}$ & $0.5335(19.37)^{* * *}$ & $0.2041(5.53)^{* * *}$ & $0.1851(9.30)^{* * *}$ \\
Constant & 16345 & 16345 & 16345 & 16345 \\
\hline Observation & $542.74 * *$ & $145.48^{* * *}$ & $126.49 * * *$ & $493.199^{* * *}$ \\
F & 0.2298 & 0.0737 & 0.0646 & 0.2132 \\
\hline Adjusted R & & &
\end{tabular}

Notes: $t$ values in parentheses. ${ }^{*}, * *$, and ${ }^{* * *}$ indicate significance at the $10 \%, 5 \%$, and $1 \%$ levels, respectively.

Table 5 reports the coefficients of the GSEM in the logit model to examine what increases the probability of having positive financial knowledge, behavior, attitude, and overall financial literacy. Like the OLS regression, we used four models for the three components and a full measure of financial literacy. The coefficients for model 1 show that a change in gender (from female to male), education, income, balance of financial assets, and use of financial information tend to increase financial knowledge, while the experience of financial trouble tends to reduce it. We found no relationship of age and the condition of being employed with financial knowledge. The coefficients for model 2 show that an increase in education, the balance of financial assets, and the use of financial information tend to increase financial behavior, while male gender, age, being employed, and the experience of financial trouble tend to decrease it. The coefficient of age squared is not significant, thus indicating that the relationship between age and financial behavior is linear. Finally, the coefficients for model 3 show that education, the balance of financial assets, and the use of financial information tend to improve financial attitude, while male gender, age, income, and experience of financial trouble tend to impair it. The coefficient of age squared is significantly negative, indicating that the relationship between age and financial attitude is not linear. Financial attitude is found to be unrelated to the condition of being employed. The coefficients for model 4 show that education, income, the balance of financial assets, and the use of financial information tend to increase financial knowledge, while a change in gender (from female to male) and the condition of being employed tend to reduce it. The coefficients of age are significantly negative, and age squared is significantly positive, indicating that the relationship between age and overall financial literacy is negative but not linear. We find no relationship of the experience of financial trouble with the overall financial literacy. The results show that the relationship of education, income, financial assets, the condition of being employed, the experience of financial trouble, and the use of financial information is largely similar to all components and the overall measure of financial literacy. However, differences exist for male gender and age across the components and the overall measure of financial literacy. Moreover, the overall results of the GSEM in logit models and the OLS models are largely similar, implying that our results are robust. 
Table 5. Generalized structural equation model (GSEM) in logit regression coefficients.

\begin{tabular}{ccccc}
\hline & $\begin{array}{c}\text { Model 1 (Financial } \\
\text { Knowledge) }\end{array}$ & $\begin{array}{c}\text { Model 2 (Financial } \\
\text { Behavior) }\end{array}$ & $\begin{array}{c}\text { Model 3 (Financial } \\
\text { Attitude) }\end{array}$ & $\begin{array}{c}\text { Model 4 (Financial } \\
\text { Literacy) }\end{array}$ \\
\hline Male & $0.5115(12.99)^{* * *}$ & $-0.1796(-5.08)^{* * *}$ & $-0.2113(-5.65)^{* * *}$ & $-0.1939(-2.88)^{* * * *}$ \\
Age & $0.0103(1.27)$ & $-0.0147(-2.04)^{* * *}$ & $-0.0260(-3.34)^{* * *}$ & $-0.0314(-2.22)^{* * *}$ \\
Age_sq & $0.0001(1.51)$ & $0.0001(1.55)$ & $-0.0002(-2.91)^{* * *}$ & $0.0006(3.77)^{* * *}$ \\
Education & $0.1577(16.34)^{* * *}$ & $0.0315(3.71)^{* * *}$ & $0.0310(3.39)^{* * *}$ & $0.1330(8.46)^{* * *}$ \\
Income & $0.0365(4.79)^{* * *}$ & $-0.0014(-0.23)$ & $-0.0131(-2.05)^{* *}$ & $0.0506(3.38)^{* * *}$ \\
Financial assets & $0.0569(15.99)^{* * *}$ & $0.0489(16.78)^{* * *}$ & $0.0417(14.45)^{* * *}$ & $0.0847(9.93)^{* * *}$ \\
Employed & $-0.0330(-0.73)$ & $-0.1023(-2.50)^{* *}$ & $-0.0665(-1.55)$ & $-0.1946(-2.45)^{* *}$ \\
Financial trouble & $-0.1376(-1.90)^{*}$ & $-0.3249(-4.99)^{* * *}$ & $-0.4264(-5.51)^{* * *}$ & $-0.1004(-0.87)$ \\
Financial & $0.8439(22.32)^{* * *}$ & $0.5609(16.19)^{* * *}$ & $0.2657(7.07)^{* * *}$ & $0.8795(12.53)^{* * *}$ \\
information & $-3.4782(-16.12)^{* * *}$ & $-0.1781(-0.93)$ & $-2.1480(-10.19)^{* * *}$ & $0.0230(0.07)$ \\
Constant & 16345 & 16345 & 16345 & 16345 \\
\hline Observation & -8715.821 & -10614.617 & -9792.497 & -3640.991 \\
Log likelihood & & &
\end{tabular}

Notes: $t$ values in parentheses. ${ }^{*}, * *$, and ${ }^{* * *}$ indicate significance at the $10 \%, 5 \%$, and $1 \%$ levels, respectively.

\section{Discussion}

Previous studies sought to explain financial literacy worldwide using conventional questions measuring financial knowledge. However, very few studies examine the factors that affect the other important components of financial literacy, such as financial behavior and financial attitude. In addition to financial knowledge, our study examined the demographic and socio-economic factors that explain financial behavior and financial attitude in Japan. Explaining financial behavior and attitude, in addition to financial knowledge, enhances the understanding and implementation of financial literacy more rigorously.

Previous studies predominantly use measures of financial knowledge in assessing financial literacy. Thus, the findings of previous studies are applicable to those of financial knowledge in our study. Our results show that financial knowledge is positively related to male gender, age, education, income, the balance of financial assets, and the use of financial information, and negatively related to the conditions of being employed and the experience of financial trouble. The results for the basic demographic variables such as male gender, age, and education support previous findings $[5,7,8,19-23,26,30,31,34]$. The reason males have more financial knowledge than females in Japanese society is that males are more exposed to the outside world than females. Traditionally, males are responsible for the economic and financial issues of the household and are more employed in formal sectors. Although both males and females get similar privileges in attaining formal education, the gender gap in financial literacy is a well-evident phenomenon in Japan. Fonseca et al. [44] argued that the characteristics of males and females cannot explain the gender gap in financial literacy. However, the process of attainment of financial literacy can explain the gap. Previous studies focusing on social learning and consumer socialization theory found that people who are more socialized tend to have more knowledge [45-47]. Based on the application of social learning and consumer socialization theories, Kadoya and Khan [26] provided evidence that males are more privileged to attain financial literacy than females. Education is an important variable, which is positively related to financial knowledge. The psychological theory that emphasizes cognitive ability explains the positive relationship between education and financial knowledge $[26,30,33]$. We argue that people can utilize the enhanced cognitive ability attained through education in the attainment of financial knowledge. Moreover, our findings of a non-linear positive relationship between age and financial knowledge confirm the findings of existing literature [7,30-32]. Middle-aged people in Japan have been found to be comparatively more financially literate than respondents in other age groups. The relationship of both income and balance of financial assets with financial knowledge generally support previous findings $[37,38]$. We also found a positive relationship between the use of financial information and 
financial literacy. People who regularly read and acquire information on financial issues tend to be more financially literate. Our results show a significantly negative relationship of financial knowledge with the experience of financial trouble and the condition of being employed. The negative relationship of the condition of being employed with financial literacy differs from previous findings of a positive relationship [23]. However, as we discussed earlier, the variable regarding the condition of being employed does not merely indicate whether respondents are employed or not; rather, it indicates their condition of employment. Thus, the negative relationship between the condition of being employed and financial knowledge indicates that full-time homemakers, students, unemployed, and employed in unspecified sectors are more likely to be financially knowledgeable than company employees, government employees, a self-employed person, and part-time employees. There could be two explanations for this seemingly unusual relationship. First, the full-time homemakers and retired persons, who comprised a major portion of this group, are likely to be financially knowledgeable. Full-time homemakers usually bear the responsibility of family financial management in Japan, and thus are more likely to be financially knowledgeable $[48,49]$. Retired people who could be unemployed are likely to be financially knowledgeable, as previous studies documented that older people in Japan are financially more literate than younger people [26,29]. Given the circumstance of the low unemployment rate in Japan, the unemployed are likely to be those who are seeking suitable jobs. Thus, students and those unemployed people could be financially knowledgeable because of their personal skills. Second, previous studies found that being employed in the formal sectors is not associated with higher financial literacy in Japan. Often, they are so busy with their job that they hardly have any intention to think about financial management. Instead, people who are employed in the financial sectors tend to be more financially literate because of their job requirements [26]. We argue that employed people do not worry much about financial knowledge to secure their future well-being, since they have a secured source of income. The other group must acquire financial knowledge to be financially successful.

In addition to financial knowledge, we related financial behavior and financial attitude to demographic and socio-economic factors. Our findings of the positive relationship of education, the balance of financial assets, and the use of financial information and the negative relationship of the conditions of being employed and experience of financial trouble are the same across financial knowledge, behavior, and attitude. However, unlike financial knowledge, males are found to have a significantly negative relationship with financial behavior and financial attitude, which indicates that males perform better than females in financial knowledge. However, females are found to have more positive financial behavior and attitude than males. Age has a non-linear positive relationship with financial knowledge but a non-linear negative relationship with financial attitude. Our results suggest that middle-aged people in Japan tend to have more financial knowledge, but younger and older people have comparatively more positive financial attitudes. Income has a positive relationship with financial knowledge but is unrelated to financial behavior and financial attitude. Being employed has a negative relationship with financial literacy and financial behavior but is unrelated to financial knowledge and financial attitude. It seems that female, younger, and older people who are usually more positive about financial behavior and financial attitude are comparatively less employed than the other groups.

The existence of differences among the relationship of males with financial knowledge, behavior, and attitude requires an explanation. Results suggest that males outperform females in financial knowledge, but females outperform males in financial behavior and financial attitude. Previous studies also suggest that financial knowledge is not always translated into financial behavior and attitude [43]. Swiecka et al. [50] found that gender makes a difference in financial behavior and the use of financial instruments but not in the level of financial knowledge. We argue that females are more conscious about the future and perceive future savings as more important than current consumption. Previous studies on consumption and savings behavior also found that females were traditionally more savings-oriented than males [51,52]. Moreover, other studies indicate that females are more risk-averse than males are, which could motivate them to save more [53]. Like males, age is inconsistently associated with 
financial knowledge, behavior, and attitude. The negative and non-linear relationship between age and financial attitude is completely different from the non-linear positive relationship of age with financial knowledge. As discussed in the previous paragraph, the positive relationship of age with financial knowledge is supported by previous findings, while the negative relationship of age with financial attitude is a new finding. It seems that younger and older people have a more positive attitude toward financial issues than do older people. Our findings on the relationship of the condition of being employed with financial knowledge, behavior, and attitude are supported by previous studies. Kadoya and Khan [26] found that employment in the financial sector, and not merely being employed, contributes to financial literacy. It seems that people do not gain knowledge on financial issues from the workplace unless their job responsibilities require them to do so. The reason behind the negative relationship could be the lack of exposure of the employed respondents to financial matters. Lack of exposure to financial matters could result in inappropriate financial behavior and a negative attitude toward financial issues.

\section{Conclusion}

Financial literacy is gaining importance as people become more involved in complex financial transactions. Having adequate financial literacy helps people to make sustainable financial decisions for their future well-being. However, relying only on financial knowledge to measure financial literacy makes the understanding of its outcome less certain. This study examines the demographic and socio-economic factors to explain financial literacy in Japan after dividing financial literacy into three components: financial knowledge, attitude, and behavior. This division allows us to provide a more rigorous understanding of the relationship of financial literacy with demographic and socio-economic variables. Our study shows that education, the balance of financial assets, and the use of financial information are positively related to financial knowledge, behavior, and attitude, while the condition of being employed and the experience of financial trouble are negatively related. Associations of other variables, such as gender and age, are found to be different across financial knowledge, behavior, and attitude. Our results provide evidence that males perform better than females in financial knowledge, though females outperform males with regard to financial behavior and financial attitude. Thus, the conventional belief that females are financially less literate than males does not hold true when financial literacy is explained from a broader perspective. Our results also show that age is positively related to financial knowledge but negatively related to financial attitude, suggesting that middle-aged people in Japan are more financially knowledgeable, but younger and older people possess more positive financial behavior and attitude.

The results of our study suggest that the government should emphasize targeted financial literacy initiatives more, as there is diversity in financial knowledge, behavior, and attitude among people. More focus should be placed on the section of people who are less financially literate and have negative financial behavior and attitude. The government should consider implementing formal financial education at school and encourage financial education at home, which will enhance financial knowledge among people and help to develop positive financial behavior and attitude. The conceptual model of Shim et al. [10] shows that financial education received at home and formal financial education at schools are likely to play anticipatory socializing roles for the acquisition of financial knowledge among young adults and shape their attitude and behavioral intentions based on that knowledge. However, Yoshino and Yamori [12] raised concerns that financial education programs at the school level in Japan are not well organized and are not conducted by well-trained teachers. The government should give special attention to these areas. Socializing financial education programs through mainstream media and trusted advice from financial experts could also help to disseminate financial literacy among people.

Our study has some limitations that should be considered while interpreting the results. First, the questions used to measure financial knowledge, behavior, and attitude are not above question. Although we followed the methodology of the OECD, the concern over the self-reported answer to the 
financial behavior and attitude questions remains an issue. Second, the study could have been extended further if there was scope to divide financial knowledge questions into the basic and advanced level. People having basic financial knowledge and advanced financial knowledge could have been from different backgrounds. These limitations should be considered while conducting future studies in this area.

Author Contributions: Conceptualization, Y.K and M.S.R.K.; methodology, Y.K and M.S.R.K.; software, Y.K and M.S.R.K.; validation, Y.K and M.S.R.K.; formal analysis, Y.K and M.S.R.K.; investigation, Y.K and M.S.R.K.; resources, Y.K.; data curation, Y.K and M.S.R.K.; writing—original draft preparation, Y.K and M.S.R.K.; writing-review and editing, Y.K and M.S.R.K.; visualization, Y.K and M.S.R.K.; supervision, Y.K.; project administration, Y.K.; funding acquisition, Y.K. All authors have read and agreed to the published version of the manuscript.

Funding: This work was supported by the JSPS KAKENHI [grant number 15K17075], [grant number 15KK0083], [grant number 19K13684], [grant number 19K13739], and RISTEX, JST.

Acknowledgments: The authors thank Nobuyoshi Yamori and Noriaki Kawamura for their helpful comments.

Conflicts of Interest: The authors declare no conflict of interest.

\section{References}

1. Knoll, M.A.; Houts, C.R. The Financial Knowledge Scale: An Application of Item Response Theory to the Assessment of Financial Literacy. J. Consum. Aff. 2012, 46, 381-410. [CrossRef]

2. OECD. The Importance of Financial Education. Policy Brief. Available online: http://www.oecd.org/finance/ financial-education/37087833.pdf. (accessed on 10 October 2019).

3. De Bondt, W.F.M. A Portrait of the Individual Investor. Behav. Econ. 1998, 42, 831-844. [CrossRef]

4. Bernheim, B.D.; Garrett, D. The Effects of Financial Education in the Workplace: Evidence from a Survey of Households. J. Publ. Econ. 2003, 87, 1487-1519. [CrossRef]

5. van Rooij, M.; Lusardi, A.; Rob Alessie, R. Financial Literacy and Stock Market Participation. J. Financ. Econ. 2011, 101, 449-472. [CrossRef]

6. van Rooij, M.; Lusardi, A.; Alessie, R. Financial Literacy, Retirement Planning and Household Wealth. Econ. J. 2012, 122, 449-478. [CrossRef]

7. Lusardi, A.; Mitchell, O.S. Financial Literacy and Retirement Planning in the United States. J. Pension Econ. Financ. 2011, 10, 509-525. [CrossRef]

8. Sekita, S. Financial Literacy and Wealth Accumulation: Evidence from Japan. Discussion Paper 2013, No. 2013-01; Graduate School of Economics, Kyoto Sangyo University: Kyoto, Japan.

9. Ye, J.; Kulathunga; KMMCB. How Does Financial Literacy Promote Sustainability in SMEs? A Developing Country Perspective. Sustainability 2019, 11, 2990. [CrossRef]

10. Shim, S.; Xiao, J.J.; Barber, B.L.; Lyons, A.C. Pathways to Life Success: A conceptual Model of Financial Well-being for Young Adults. J. Appl. Dev. Psychol. 2009, 30, 708-723. [CrossRef]

11. Furusawa, T. Developments of Financial Education in Japan. In Proceedings of the JFSA-ADBI-IMF Joint Conference, Tokyo, Japan, 27 January 2014.

12. Yoshino, N.; Yamori, N. Financial Education in Japan. In Promoting Better Lifetime Planning through Financial Education; Yoshino, N., Messy, F.-A., Morgan, P.J., Eds.; World Scientific Publishing Co: Singapore, 2016; pp. 98-103.

13. Marcolin, S.; Abraham, A. Financial Literacy Research: Current Literature and Future Opportunities. Available online: http://ro.uow.edu.au/commpapers/223/. (accessed on 9 October 2019).

14. Schmeiser, M.D.; Seligman, J.S. Using the Right Yardstick: Assessing Financial Literacy Measures by Way of Financial Well-Being. J. Consum. Aff. 2013, 47, 243-262. [CrossRef]

15. Huston, S.J. Measuring Financial Literacy. J. Consum. Aff. 2010, 44, 296-316. [CrossRef]

16. U.S. Financial Literacy and Education Commission. Taking Ownership of the Future: The National Strategy for Financial Literacy. Available online: https:/www.treasury.gov/about/organizational-structure/offices/ Domestic-Finance/Documents/Strategyeng.pdf (accessed on 10 October 2018).

17. Jump\$tart Coalition. National Standards in K-12 Personal Finance Education. Available online: http: //www.jumpstart.org/guide.html (accessed on 23 October 2019).

18. OECD. PISA 2015 Results: Students' Financial Literacy; OECD Publishing: Paris, France, 2017; Volume 4. 
19. Atkinson, A.; Messy, F. Measuring Financial Literacy: Results of the OECD/International Network on Financial Education (INFE) Pilot Study. OECD Working Papers on Finance, Insurance and Private Pensions; OECD Publishing: Paris, France, 2012.

20. Alessie, R.; Bucher-Koenen, T.; Lusardi, A.; Van Rooij, M. Gender, Confidence and Financial Literacy. In Proceedings of the Neuro Psycho Economics Conference, Bonn, Germany, 6-7 June 2013.

21. Brown, M.; Graf, R. Financial Literacy and Retirement Planning in Switzerland. Available online: http: //scholarcommons.usf.edu/cgi/viewcontent.cgi?article=1133\&context=numeracy (accessed on 22 June 2019).

22. Hung, A.; Yoong, J.; Brown, E. Empowering Women Through Financial Awareness and Education. OECD Working Papers on Finance, Insurance and Private Pensions; OECD Publishing: Paris, France, 2012.

23. Lusardi, A.; Mitchell, O.S. Financial Literacy Around the World: An Overview. J. Econ. Financ. 2011, 10, 497-508.

24. Kadoya, Y.; Khan, M.S.R.; Hamada, T.; Dominguez, A. Financial Literacy and Anxiety About Life in Old Age: Evidence from the USA. Rev. Econ. Househ. 2018, 16, 859-878. [CrossRef]

25. Kadoya, Y.; Khan, M.S.R. Can Financial Literacy Reduce Anxiety About Life in Old Age? J. Risk Res. 2018, 21, 1533-1550. [CrossRef]

26. Kadoya, Y.; Khan, M.S.R. What Determines Financial Literacy in Japan? J. Pension Eco. Financ. 2019. [CrossRef]

27. Kadoya, Y.; Khan, M.S.R.; Oba, H.; Narumoto, J. Factors affecting knowledge about the adult guardianship and civil trust systems: Evidence from Japan. J. Women Aging 2020. [CrossRef] [PubMed]

28. Watanapongvanich, S.; Binnagan, P.; Putthinum, P.; Khan, M.S.R.; Kadoya, Y. Financial Literacy and Gambling Behavior: Evidence from Japan. J. Gambl. Stud. 2020. [CrossRef]

29. Sekita, S. Financial Literacy and Retirement Planning in Japan. J. Pension Econ. Financ. 2011, 10, 637-656. [CrossRef]

30. Lusardi, A.; Mitchell, O.S.; Curto, V. Financial Literacy Among the Young: Evidence and Implications for Consumer Policy. J. Consum. Aff. 2010, 44, 358-380. [CrossRef]

31. Lusardi, A.; Mitchell, O.S. The Economic Importance of Financial Literacy: Theory and Evidence. J. Econ. Lit. 2014, 52, 5-44. [CrossRef]

32. Agarwal, S.; Driscoll, J.C.; Gabaix, X.; Laibson, D. The Age of Reason: Financial Decisions Over the Lifecycle. Brook. Pap. Econ. Act. 2009, 2, 51-117. [CrossRef]

33. Gill, D.; Prowse, V. Cognitive Ability, Character Skills, and Learning to Play Equilibrium: A Level-K Analysis. J. Polit. Econ. 2015, 124, 1619-1676. [CrossRef]

34. Danes, S.M.; Haberman, H. Teen Financial Knowledge, Self-efficacy, and Behavior: A Gendered View. J. Financ. Couns. Plan. 2007, 18, 48-60.

35. Urban, C.; Schmeiser, M.; Collins, J.M.; Brown, A. The Effects of High School Personal Financial Education Policies on Financial Behavior. Econ. Educ. Rev. 2018, 17, 101786. [CrossRef]

36. Monticone, C. How Much Does Wealth Matter in the Acquisition of Financial Literacy. J. Consum. Aff. 2010, 44, 403-422. [CrossRef]

37. Lusardi, A.; Tufano, P. Debt Literacy, Financial Experiences, and Overindebtedness. National Bureau of Economic Research Working Paper 14808; National Bureau of Economic Research: Cambridge, MA, USA, 2009.

38. Guiso, L.; Jappelli, T. Financial Literacy and Portfolio Diversification. EUI Working Paper, (ECO 2008/31); European University Institute: Florence, Italy, 2008.

39. Lusardi, A.; Mitchell, O.S. Financial Literacy and Retirement Preparedness: Evidence and Implications for Financial Education. Bus. Econ. 2007, 42, 35-44. [CrossRef]

40. Lusardi, A.; Mitchell, O.S. Planning and Financial Literacy: How do Women Fare? Am. Econ. Rev. 2008, 98, 413-417. [CrossRef]

41. FINRA, I.E.F. Financial Capability in the United States: Report of Findings from the 2012 National Financial Capability Study; FINRA Investor Education Foundation: Washington, DC, USA, 2013.

42. Xiao, J.J.; Porto, N. Present Bias and Financial Behavior. Financ. Plan. Rev. 2019, 2, e1048. [CrossRef]

43. Fabrigar, L.R.; Petty, R.E.; Smith, S.M.; Crites Jr., S. L. Understanding Knowledge Effects on Attitude-Behavior Consistency: The Role of Relevance, Complexity, and Amount of Knowledge. J. Personal. Soc. Psychol. 2006, 90, 556-577. [CrossRef]

44. Fonseca, R.; Kathleen, J.M.; Gema, Z.; Zissimopoulos, J. What Explains the Gender Gap in Financial Literacy? The Role of Household Decision-Making; Rand Corporation: Santa Monica, CA, USA, 2010. 
45. Bandura, A.; Walters, R.H. Social Learning Theory; General Learning Press: New York, NY, USA, 1977.

46. Hira, T.K. Financial Attitudes, Beliefs, and Behaviours: Differences by Age. J. Consum. Stud. Home Econ. 1997, 21, 271-290. [CrossRef]

47. Martin, C.A.; Bush, A.J. Do Role Models Influence Teenagers' Purchase Intentions and Behavior? J. Consum. Mark. 2000, 17, 441-454. [CrossRef]

48. Hilary, M. Kakeibo Monogatari: Women's Consumerism and the Postwar Japanese Kitchen, 1945-1964; Scholars' Bank, University of Oregon: Eugene, OR, USA, 2018.

49. Komori, N. Visualizing the Negative Space: Making Feminine Accounting Practices Visible by Reference to Japanese Women's Household Accounting Practices. Crit. Perspect. Account. 2012, 23, 451-467. [CrossRef]

50. Swiecka, B.; Yeşildağ, E.; Özen, E.; Grima, S. Financial Literacy: The Case of Poland. Sustainability 2020, 12, 700. [CrossRef]

51. Lee, J.; Pocock, M.L. Intrahousehold Allocation of Financial Resources: Evidence from South Korean Individual Bank Accounts. Rev. Econ.Househ. 2007, 5, 41-58. [CrossRef]

52. Hungerford, T. Saving for a Rainy Day: Does Pre-Retirement Access to Retirement Savings Increase Retirement Saving? Social Security Administration: Wooldand, MD, USA, 1999.

53. Jianakoplos, N.; Bernasek, A.; Bernasek, A. Are Women More Risk Averse? Econ. Inq. 1998, 36, $620-630$. [CrossRef]

(C) 2020 by the authors. Licensee MDPI, Basel, Switzerland. This article is an open access article distributed under the terms and conditions of the Creative Commons Attribution (CC BY) license (http://creativecommons.org/licenses/by/4.0/). 